\title{
On the Effects of Focus on Form, Focus on Meaning, and Focus on Forms on Learners' Vocabulary Learning in ESP Context
}

\author{
Mahnaz Saeidi ${ }^{1}$, Elaheh Zaferanieh ${ }^{2} \&$ Hafez Shatery ${ }^{3}$ \\ ${ }^{1}$ Department of English, Tabriz Branch, Islamic Azad University, Tabriz, Iran \\ ${ }^{2}$ Department of English, Mashhad Branch, Islamic Azad University, Mashhad, Iran \\ ${ }^{3}$ Department of English, Sirjan Branch, Islamic Azad University, Sirjan, Iran \\ Correspondence: Elaheh Zaferanieh, Mashhad Branch, Islamic Azad University, Iran. E-mail: \\ e.zaferanieh@yahoo.com
}

Received: March 28, 2012 Accepted: July 12, 2012 Online Published: August 16, 2012

doi:10.5539/elt.v5n10p72 URL: http://dx.doi.org/10.5539/elt.v5n10p72

\begin{abstract}
This study investigated the effectiveness of three kinds of vocabulary instruction. Seventy learners in the classes of English for Specific Purposes (ESP) were divided into three different groups receiving different instructions: Focus on Form Instruction (FoF) (Dictogloss task), Focus on Meaning Instruction (FoM) (Reading and Discussion task), and Focus on Forms (FoFs) Instruction (Word lists). The first two groups were experimental groups, and the last group was control group. The results of this research indicated that learners in FoF group achieved significantly higher scores than those in FoM and FoFs. Also, learners' scores in FoM group were significantly higher than FoFs group. These findings were justified by main features of FoF tasks (dictogloss) including depth of processing hypothesis, discovery learning, pushed output, noticing hypothesis, awareness raising, negotiation, collaboration, and motivation.
\end{abstract}

Keywords: Focus on Form, Focus on Forms, Focus on Meaning, dictogloss, English for Specific Purposes

\section{Introduction}

In second language acquisition (SLA), there is a debate between those researchers who claim that in SLA mere exposure to meaningful input and learning through language use is enough, and those who argue that only a conscious attention to form is necessary.

The first group refers to purely communicative instruction, or what they call focus on meaning instruction. For them, teaching with focus on meaning is paramount to spending little or no time on the discrete parts of language; instead, the interest is on the use of language in real-life situations. Such a mode of instruction is apparent in the Natural Approach (Krashen \& Terrel, 1983), which, in theory, prohibits direct teaching (Ellis, Loewen \& Basturkmen, 2006; Paradowski, 2007).

The second group as the proponents of Focus on Forms Instruction believes that second language learners could not achieve high levels of linguistic competence (Grammar, vocabulary, phonology) from entirely meaning-centered instruction. Thus, they concluded that instruction makes a difference in SLA and mere exposure to input does not lead to develop into accurate acquisition (Ellis, 2001; Le Fuente, 2006; Bourke, 2008).

During the debates between these two groups, Long (1991) and Long and Robinson (1998) assert that the occasional focus on the discrete-forms of the L2 via correction, negative feedback, direct explanations, recasts, etc., can help students become aware of, understand, and ultimately acquire difficult forms. So, in sum, according to Long (1991) and Long and Robinson (1998), both Focus on Forms and Focus on Meaning instructions are valuable, and should complement rather than exclude each other. Focus on Form instruction, in their view, maintains a balance between the two by calling on teachers and learners to attend to form when necessary, yet within a communicative classroom environment.

Focus on Form instruction was introduced when some researchers such as Swain (1998), and Lyster (1998) showed that second language learners could not achieve high levels of grammatical competence from entirely meaning-centered instruction; therefore, some scholars suggested that learners should also attend to form (Long 
1991). In other words, by the appearance of communicative views of language teaching, a gradual shift occurred form the old-fashioned stance of synthetic syllabus to analytic syllabus. Thus, some theories, such as Monitor Theory of SLA by Krashen (1985, cited in Doughty \& Williams, 1998) and Output Hypothesis by Swain (1993) put mere focus on communication and meaning rather than focus on form and accuracy. In fact, the first stance related to synthetic syllabus leads to focus on forms, the controversial issue of teaching about the language not teaching the language, and the latter associated with analytic syllabus leads to discarding grammar, and, as a result, inaccuracy in language acquisition; consequently, Focus on Form instruction to second language teaching is a kind of improvement in communicative language teaching (Long and Robinson, 1998).

Regarding these instructions, the point which seems necessary to be mentioned is that the two terms Focus on Form and Focus on Forms should not be confused and used interchangeably. While Focus on Form refers to drawing learners' attention to linguistic elements during a communicative activity (Long, 1991, p. 46), Focus on Forms refers to teaching discrete linguistic structures in separate lessons based on structural syllabus. In addition, Focus on Forms instruction is teacher-centered. Focus on form instruction, in contrast, is learner-centered due to its aim of responding to learners' perceived needs in a spontaneous manner (Ellis, 2008, p. 962).

The notion of Focus on Form instruction was first introduced for teaching grammar, and there were researchers such as Doughty and Verela (1998), Williams and Evans (1998), and Van Patten and Oikkenon (1996) who studied this kind of instruction in learning grammatical rules. However, it has been mentioned that such an instruction can be applied for teaching vocabulary too (Doughty \& Williams, 1998), so that learning new words in a list without involving in a communicative task is FoFs, and learning vocabulary while doing a communicative task is FoF. Doughty and Williams (1998, p. 212) declared "it is likely that focus on form can enhance lexical acquisition, and there is mounting evidence that, in the acquisition of lexical items, as with that of grammatical structures, some interaction is helpful". Empirical research of form-focused instructions whether FoF, or FoFs has been conducted mainly in the context of the teaching of grammar, not vocabulary or collocations, so that, number of studies investigating and comparing three FoF, FoFs, and FoM instructions in vocabulary learning is rare. Therefore, there is a need to research and study the effects of these three instructions in vocabulary teaching (Hulstijn, 1992), especially in ESP contexts in which second language vocabulary is an indispensible part of second language teaching and learning.

According to what was mentioned above, this study aims to examine teaching vocabulary through Focus on Form (FoF), Focus on Meaning (FoM) and Focus on Forms (FoFs) instructions in ESP context. So the research question in this study is: Is there a difference on the achievement of the participants' vocabulary learning in post-tests among FonF group, FonFs group, and FonM group?

\section{Definition of Some Key Terms}

Dictogloss: Dictogloss is a form of dictation, in which the students hear and reconstruct the whole text rather than doing so line by line (Wajnryb 1990).

Focus on Form (FonF): Focus on form: Focus on Form "consists of an occasional shift of attention to linguistic code features - by the teacher and/or one or more students - triggered by perceived problems with comprehension or production"(Long \& Robinson, 1998, p. 23).

Focus on Forms: (FonFs): Focus on Forms refers to the presentation of discrete items of grammar, lexis, functions, and notions one at a time, like the presentation of a grammatical point traditionally (Long, 1997).

Focus on Meaning: In Focus on Meaning, it is believed that people of all ages learn languages best, not by treating languages as an object of study, but by experiencing them as a medium of communication (Long \& Robinson, 1998).

Productive vocabulary knowledge: Productive knowledge is the ability to produce the words in appropriate contexts. In this research, it was the participants' scores on a fill-in-the-blank test devised by the researcher.

\section{Review of Literature}

Traditionally, there have been different kinds of instructions for teaching second language and its different aspects. These instructions were derived from specific syllabus designs. Long and Robinson (1998) state that previously, the first task in syllabus design was to analyze the target language to form a pedagogical grammar, which is termed by Wilkins (1976, cited in Long \& Robinson, 1998) as syntheticapproach, in which the language is broken down into words, grammar rules, ... and leads to focus on forms; in which discrete items of grammar, lexis, functions, and notions are presented one at a time.

However, in practice, it was found that this kind of syllabus did not work as it was predicted, so the movement 
from focus on forms to equally single minded "focus on meaning" started. Some researchers such as Corder (1967) and Krashen (1985) considered focus on meaning through incidental L2 learning and exposure to comprehensible input is sufficient in L1 acquisition by young children, which should also be used as the basis for L2 or foreign language acquisition. For instance, Krashen refers to consciously learned and unconsciously acquired language in his Monitor Theoryof SLA (Doughty \& William, 1998).

Doughty and Williams (1998) mention that regarding the Monitor Theory no solution is provided for the lack of accuracy in adult L2 learning. This kind of language learning, which holds that language should be learned by experiencing it as a medium of communication, forms the base for analytic syllabuswhich is defined by Wilkins (1976, cited in Long \& Robinson, 1998) as the organization of "purposes for which people are learning language and the kinds of language performance that are necessary to meet those purpose" (p. 18).

Regarding researches related to only focus on meaning and comprehensible input (Long, 1990, cited in Long \& Robinson, 1998), Long and Robinson (1998) argued that mere exposure to language use and focus on meaning is not enough.

In addition, the insufficiency of focus on meaning can be found in researches related to fossilization. Brown (2000) mentions that in some learners, despite high level of language knowledge, certain erroneous features could still be seen in their interlanguage. These incorporated erroneous linguistic forms are considered as fossilized forms which could be rectified, but not very easily.

At this point, Long and Robinson (1998, p. 21) call for a kind of support but this does not mean to move back to focus on forms, but rather "Focus on Form (FonF)" is put forward which keeps the strengths of synthetic syllabus and removes its limitations. This approach is motivated by Interaction Hypothesis (Long, 1983, cited in Long \& Robinson, 1998) according to which interaction between learners and adults, or moreproficient speakers, as well as texts, especially the elaborated ones, plays acrucial role in language development. This development occurs especiallyby the negotiation of meaning between the two sides, which ends in modifications to the interactional structure of conversation (Long, 1997, cited in Long \& Robinson, 1998). Focus on Form, in contrast to Focus on Forms consists of "an occasional shift of attention to linguistic code features- by the teacher and/or one or more learners - triggered by perceived problems with comprehension or production" (Long \& Robinson, 1998, p. 23).

\section{Focus on Form Tasks and Techniques}

Doughty and Williams (1998, cited in Saeidi, 2007) presented a taxonomy of tasks and techniques. It is as a continuum based on degree of obtrusiveness of Focus on Form. In other words, this taxonomy shows that how tasks and techniques can be ranged along a continuum reflecting the degree to which the focus on form interrupts the flow of communication. These tasks and techniques from unobtrusive to obtrusive ones are:

\begin{tabular}{|c|c|c|c|}
\hline Unobtrusive & & & Obtrusive \\
\hline Focus on Form & & & Focus on Form \\
\hline Input flood & $\mathrm{X}$ & & \\
\hline Task-essential language & $\mathrm{X}$ & & \\
\hline Input enhancement & $\mathrm{X}$ & & \\
\hline Negotiation & $\mathrm{X}$ & & \\
\hline Recast & $\mathrm{X}$ & & \\
\hline Output enhancement & $\mathrm{X}$ & & \\
\hline Interaction enhancement & & $\mathrm{X}$ & \\
\hline Dictogloss & & & $\mathrm{X}$ \\
\hline CR tasks & & & $\mathrm{X}$ \\
\hline Input processing & & & $\mathrm{X}$ \\
\hline Garden path & & & $\mathrm{X}$ \\
\hline
\end{tabular}

Figure 1.

In other classification, Ellis (2003) has suggested three principal ways that researchers set about designing focused tasks: Structured based production tasks (Dictogloss and text reconstruction tasks), Comprehension tasks (Interpretation task), and Consciousness-raising tasks.

As it is evident in these classifications, it is possible to combine different explicit and implicit instructions; 
however, what is important is integrating form, meaning, and use (Saeidi, 2007).

\section{Related Empirical Studies}

A look at recent research in the area of second language acquisition reveals that focus on form instruction has been empirically evaluated using a variety of methodologies.

Doughty and Verela (1998) examined the differences in the acquisition of English tense between junior high US ESL science students who received corrective recasts and those who received teacher-led instruction, mostly in the form of lectures. Regardless of the type of instruction they were exposed to, learners took pre-tests and post-tests. Those students who received corrective recasts performed significantly better on post-tests than did those who received teacher-led instruction.

Williams and Evans (1998) studied the precision with which intermediate-level ESL learners used the passive voice and adjectival participles. Two groups were established, one which received input flooding, and one which acted as a control group. The results demonstrated that the experimental group showed more accurate use of the passive than did the control group, yet no significant differences were seen between the groups in terms of their use of adjectival participles.

Van Patten and Oikkenon (1996) investigated the effects of processing instruction on a group of secondary students studying Spanish at the intermediate level. Processing instruction involves an explicit explanation of a certain grammatical rule, followed by contextualized practice activities. Participants were divided into three groups, one which received explicit explanations of rules, one which received contextualized practice activities, and one which received both explicit explanations of rules and contextualized practice activities. They found that those who only received explicit explanations retained the fewest grammatical rules; the other two groups, on the other hand, achieved significantly higher scores on post-treatment tests.

From above mentioned studies, it is indicated that empirical research of form-focused instructions has been conducted mainly in the context of the teaching of grammar, not other aspects such as vocabulary or collocations so that number of studies investigating and comparing three FoF, FoFs, and FoMinstructions in vocabulary is rare. While vocabulary is very significant in SLA, so there is need for investigating and studying the effects of these three kinds of instructions on vocabulary learning.

\section{Method}

\subsection{Participants}

Participants in this study were70 Iranian University students, consisting both males and females, with the age between 19-22, majoring in architect engineering, making up three English classes at Islamic Azad University of Mashhad.

\subsection{Instruments}

In this study, the participants' general proficiency was assessed through Nelson English Test to ensure the homogeneity of the groups at the beginning of treatment. This test has three sections: cloze tests, structure, and vocabulary. In addition, in this work, researcher-made test of vocabulary as both pre-test and post-test was developed and used. This test was a kind of productive test. It contains fill in the blank questions in which learners are supposed to produce and write the new words.

\subsection{Procedure}

This study required homogeneous learners who also had almost no familiarity with new L2 words (these words were technical words related to their field of study). At first, Nelson English language test was used to assure that learners were in the same proficiency level. Then researcher-made vocabulary test as a pre-test was administered. In the next step, learners were divided into three different groups receiving different instructions: Focus on Form Instruction (Dictogloss task), Focus on Meaning Instruction (Discussion task), and Focus on Forms Instruction (Word lists). The first two groups were experimental groups, and the last group was control group.

In FoF group being involved in dictogloss task, the teacher introduced the topic by asking questions about the text in order to awaken their background knowledge. Then, students were asked to read a text. When reading was completed, the teacher went over the students and addressed any questions or comments from the learners. After completing the text, they received form-focused task, dictogloss. In this task, teachers read a short text containing new words twice and at a normal speed to students. The students listened very carefully and wrote down as much information as they could as they listened. When the reading was finished, the students were divided into small groups of three and were asked to use their notes in order to reconstruct the text as closely as possible to the original version. At last, they were asked to compare and analyze the different versions they 
produced.

In the second group, Focus on Meaning, the first part of this treatment was similar to the FoF group. Firstly, the teacher talked about the topic in order to awaken learners' background knowledge. Then, the teacher asked students to read a text and state the main idea of each paragraph. Upon the completion of the text, learners received communicative, pair/group discussion task.

Within the FoFs group, the teacher discussed the topic of the text in order to activate learners' knowledge. Then, students were given lists of new words along with their Farsi equivalents, and they were asked to memorize the new words.

At last, the teacher-made vocabulary test was administered as the post-test of the learners' achievement in new words.

\subsection{Data Analysis}

In this study, the independent variable was the instructional method which had three levels: FoF, FoM, and FoFs. The dependent variable was the participants' productive knowledge in post-test. The design to carry out this study was experimental, with a pretest, three different treatments for experimental and control groups, as well as a post-test. To answer the research questions regarding the difference between the three different instructions, in this study one-way ANOVA and post hoc analysis were used.

\section{Results}

At first, a One-Way ANOVA based on the participants' scores on the Nelson Test was utilized to establish the homogeneity of the three groups exposed to FoF, FoM, FoFs instructional methods. The results confirmed that the three groups were homogeneous with respect to their language proficiency levels $(F=.075, p=.928)$. Then to ensure the homogeneity of three groups' scores in pretest, one-way ANOVA was used and the results confirmed that all learners in three groups had low knowledge of the words and there was no difference between three groups (see Table 1).

Table 1. One-way ANOVA Results for Pretest Scores in Three Groups

\begin{tabular}{llllll}
\hline & \multicolumn{2}{l}{ Sum of } & & & \\
& Squares & df & Mean Square & F & Sig. \\
\hline Between Groups & 1.342 & 2 & .671 & .449 & .640 \\
Within Groups & 101.644 & 68 & 1.495 & & \\
Total & 102.986 & 70 & & & \\
\hline
\end{tabular}

After the treatment and administering the post test, again one-way ANOVA was conducted to see whether three groups were significantly different. The results of ANOVA analyses revealed a significant difference between the three groups (see Table 2), but to identify which instructional approaches produced the significant results further post-hoc analyses were conducted. Scheffe method of post hoc analysis was used for this purpose (see Table 3). The findings showed that learners' scores in FoF group were significantly better than those of FoM group, and both of them achieved better scores than FoFs group.

Table 2. One-way ANOVA Results for Posttest Scores in Three Groups

\begin{tabular}{llllll}
\hline & \multicolumn{2}{l}{ Sum of } & & & \\
& Squares & df & Mean Square & F & Sig. \\
\hline Between Groups & 741.855 & 2 & 370.927 & 37.360 & .000 \\
Within Groups & 675.131 & 68 & 9.928 & & \\
Total & 1416.986 & 70 & & & \\
\hline
\end{tabular}


Table 3. Scheffe Test Multiple Comparisons

\begin{tabular}{llllll}
\hline & $\begin{array}{l}\text { Mean } \\
\text { Difference } \\
\text { (I-J) }\end{array}$ & Sig.Error & Sig & \multicolumn{2}{l}{$\begin{array}{l}95 \% \text { Confidence } \\
\text { Interval }\end{array}$} \\
\cline { 4 - 6 }$(\mathrm{J})$ method & & & & Lower Bound & $\begin{array}{c}\text { Upper } \\
\text { Bound }\end{array}$ \\
\hline FoFsFoM & & & & & -2.81 \\
FoF & $-5.16206^{*}$ & .93966 & .000 & -7.5137 & -5.45 \\
\hline FoMFoFs & $-7.70401^{*}$ & .90196 & .000 & -9.9613 & 7.51 \\
FoF & $5.16206^{*}$ & .93966 & .000 & 2.8104 & -2.58 \\
\hline FoFFoFs & $-2.54196^{*}$ & .91277 & .025 & -4.8263 & 9.96 \\
FoM & $7.70401^{*}$ & .90196 & .000 & 5.4467 & 4.83 \\
\hline
\end{tabular}

*. The mean difference is significant at the .05 level.

\section{Discussion}

This study investigated the effectiveness of three kinds of instruction: Focus on Form, Focus on Meaning, and focus on Forms. The results of this research indicated that learners in FoF group achieved significantly higher scores than those in FoM and FoFs. Also, learners' scores in FoM group were significantly higher than FoFs group.

These findings are consistent with Doughty and Verela (1998) research who found that using Focus on Form tasks were effective in language learning. However, their research was related to acquisition of English tense.

In addition, the results of this study are in accord with Williams and Evans (1998) study who demonstrated that the group with Focus on Form tasks showed more achievements.

Also, the results of current study confirm Long and Robinson's (1998) argument that both Focus on Forms and Focus on Meaning instructions are valuable, and should complement rather than exclude each other. Focus on Form instruction, in their view, maintains a balance between the two by calling on teachers and learners to attend to form when necessary, yet within a communicative classroom environment.

Moreover, the finding that in productive vocabulary tests FoFs group did a rather poor job in comparison with two other groups is in line with Craik and Tulving's depth of processing hypothesis (1975) to the effect that "the more cognitive energy a person expends when manipulating a word and thinking about it, the more likely it is that he/she will be able to use it later" (as cited in Segler, 2000). In other words, productive knowledge involves recognition of the new words as well as production. New words to be produced need to form memory traces that are well consolidated, and based on the depth of processing hypothesis, this consolidation occurs only in deeper levels of processing such as learning the words in the context. In FoFs vocabulary learning, because of just memorization of word lists, the level of processing is not deep, and memory traces are not consolidated enough to enable learners perform well on productive tests.

The superiority of dictogloss in FoF instruction can also be justified by the discovery nature of such an approach. According to Rod Ellis (2005) discovery activities can assist learners to use explicit knowledge to facilitate the acquisition of implicit knowledge. Based on Fotos and Nassaji (2011), there are some theoretical positions that support the view of discovery learning in FoF. One of them is deep processing in which learners are involved, the other one is self-investment since learners need to be motivated both instrumentally and integratively (Dornyei, 2001) and this can be achieved through approaches which excite the curiosity of learners in relation to a language feature (Fotos and Nassaji, 2011, p. 179).

Besides to these, it has been mentioned that such approaches help learners notice features of their input both on the sense of paying attention to features they may be unaware of and in the sense of being alerted to gaps between their language performance and proficient language users. Noticing these gaps help learners attend to related features of language use in subsequent input and facilitates learning (Schmidt \& Frota, 1986; Ellis, 2002; Swain, 2005).

The finding of this study regarding the better achievement of FoF group highlights the importance of negotiation and collaboration. Negotiation is helpful since from input-output perspective, it provides opportunities for comprehensible input and pushed output which improves accuracy (Swain, 1985 as cited in Fotos and Nassaji, 2011, p. 128). From a socio-cultural perspective, negotiation provides opportunities for scaffolding that is 
supportive conditions created through social interaction. Also, during negotiation learners have opportunities to find out and self correct their own errors (Fotos and Nassaji, 2011, p.128).

Providing raising awareness, noticing the gap, and collaboration are the main goals of dictogloss as one kind of FoF tasks, and so a good reason for such results in the current study.

\section{Conclusion}

The aim of this study was to investigate the effectiveness of three kinds of vocabulary instruction: Focus on Form, Focus on Meaning, and Focus on Forms. The results of this research indicated that learners in FoF group achieved significantly higher scores than those in FoM and FoFs. Also, learners' scores in FoM group were significantly higher than FoFs group. These findings were related to main goals and features of FoF tasks (ditogloss) including depth of processing hypothesis, discovery learning, pushed output, noticing hypothesis, awareness raising, negotiation, collaboration, and motivation.

The finding of this study have some implications for second language teachers since they would be aware of which kinds of instruction (focus on form, focus on forms or focus on meaning) would be more effective in vocabulary learning in ESP context. In addition, they will know different techniques for application of these instructions especially FoF in classroom context. Thus, the results of this study can provide teachers with some guidelines to overcome the ongoing challenge of the best method of teaching L2 words. In addition, the results of this research can have implications for material developers since one of the responsibilities of material developers is to provide and sequence the content of teaching materials, especially the tasks, so the findings of this research may help them design tasks to provide opportunities for focus on the most effective approach.

However, there are certain delimitations in this study. First, this study is limited to beginning proficiency level. There can be more in investigations for intermediate and advanced levels of proficiency to infer some generalizations. Second, in this study, dictogloss as a FoF technique was used. There are some other tasks and techniques that can be considered in such investigations. Third, the participants were Iranian, so the results cannot be generalized to learners of other nationalities.

\section{References}

Bourke, J. M. (2008). A rough guide to language awareness. English teaching forum, 2, $12-21$.

Brown, H. D. (2000). Principles of language learning and teaching $\left(4^{\text {th }}\right.$ ed.). New York: A Pearson Education Company.

Corder, S. P. (1967). The significance of learner's errors. IRAL, 5, 161-170. http://dx.doi.org/10.1515/iral.1967.5.1-4.161

Craik, F. I. M., \& Tulving, E. (1975). Depth of processing and the retention of words in episodic memory. Journal of Experimental Psychology: General, 104, 268-294.

De la Fuente, M. J. (2006). Classroom L2 vocabulary acquisition: investigating the role of pedagogical tasks and form-focused instruction. Language teaching Research, 10, 263-295. http://dx.doi.org/10.1191/13621688061r196oa

Dornyei, Z. (2001). Motivational Strategies in Language Classroom. Cambridge: Cambridge University Press. http://dx.doi.org/10.1017/CBO9780511667343

Doughty, C., \& Varela, E. (1998). Communicative focus on form. In C. Doughty, \& J. Williams (Eds.), Focus on form in classroom secondlanguage acquisition (pp. 114-138). Cambridge: Cambridge University Press.

Doughty, C., \& Williams, J. (1998). Pedagogical choices in focus on form. In C. Doughty, \& J. Williams (Eds.), Focus on form in classroomsecond language acquisition (pp. 197-261). Cambridge: Cambridge University Press.

Ellis, R. (2001). Investigating form-focused instruction. In Ellis, R. (Ed.), Form Focused Instruction in Second Language Learning. Blackwell, Oxford (in press).

Ellis, R. (2002). Does form-focused instruction affect the acquisition of implicit knowledge? Studies in Second Language Acquisition, 24(2), 223-226. http://dx.doi.org/10.1017/S0272263102002073

Ellis, R. (2003). Task-based Language Learning and Teaching. Oxford: Oxford University Press.

Ells, R. (2005). Instructed language learning and task-based teaching. In E. Hinkel (ed.), Handbook of Research in Second Language Teaching and Learning. Mahwah, N.J.: Lawrence Erlbaum Associates.

Ellis, R. (2008). The study of second language acquisition. Oxford: Oxford University Press. 
Ellis, R., Loewen, S., \& Basturkmen, H. (2006). Disentangling Focus on form. A response to Sheen and O'Neill (2005). Applied Linguistics, 27, 135-141.

Fotos, S., \& Nassaji, H. (2011). Form-focused Instruction and Teacher Education, Studies in Honor of Rod Ellis. Oxford: Oxford University Press.

Hulstijn, J. (1992). Retention of inferred and given word meanings: Experiments in incidental vocabulary learning. In P Arnaud, \& H. Bejoint (Eds.), Vocabulary and Applied Linguistics (pp. 113-125). London: Macmillan Academic and Professional Limite.

Krashen, S. (1985). The Input Hypothesis. Oxford: Pergamon Press.

Krashen, S., \& Terrel, T. (1983). The Natural Approach: Language Acquisition in the Classroom. Oxford: Pergamon Press.

Long, M. H. (1977). Teacher feedback on learner error: mapping cognitions. In Brown, H. D., Yorio, C. A., \& Crymes, R. (eds.), On TESOL '77. Teaching and learning English as a Second Language: Trends in research and practice (pp. 278-94). Washington, D. C.

Long, M. H. (1983). Does second language instruction make a difference? A review of research. TESOL Quarterly, 17, 359-382.

Long, M. H. (1990). The least a second language acquisition theory needs to explain. TESOL Quarterly, 24, 649-666.

Long, M. H. (1991). Focus on form: A design feature in language teaching methodology. In K. de Bot, R. Ginsberg, \& C. Kramsch (Eds.), Foreign language research in cross-cultural perspective (pp. 39-52). Amsterdam: John Benjamins.

Long, M., \& Robinson, P. (1998). Focus on form: Theory, research and practice. In C. Doughty, \& J. Williams (Eds.), Focus on form in classroom second language acquisition (pp. 15-41). Cambridge, England: Cambridge University Press.

Lyster, R. (1998). Recasts, repetition, and ambiguity in L2 classroom discourse. Studies in Second Language Acquisition, 20, 51-81. http://dx.doi.org/10.1017/S027226319800103X

Paradowski, M. B. (2007). Unity of formal instruction and focus on form in language teaching. Exploring the L1/L2 interface. A study of Polish Advanced EFL Learners. Institute of English studies, University of Warsaw, 64-85.

Saeidi, M. (2007). Multiple Intelligence-Based Focus on Form Approach: From Theory to Practice. Tabriz: Islamic Azad University- Tabriz Branch.

Schmidt, R., \& Frota, S. (1986). Developing basic conversational ability in a second language: a case study of an adult learner of Portuguese. In R. Day (ed.), Talking to Learn: Conversation in Second Language Acquisition. Rowley, Mass: Newbury House.

Swain, M. (1985). Communicative competence: some rules of comprehensible input and comprehensible output in its development. In S. Gass, \& C. Madden (ed), Input in Second Language Acquisition. Rowley, Mass: Newberry House.

Swain, M. (1993). The output hypothesis: Just speaking and writing aren't enough. The Canadian Modern Language Review, 50, 158-164.

Swain, M. (1998). Focus on form through conscious reflection. In C. Doughty, \& J. Williams (Eds.), Focus on form in classroom secondlanguage acquisition (pp. 64-81). Cambridge: Cambridge University Press.

Swain, M. (2005). The output hypothesis: theory and research. In E. Hinkel (ed), Handbook on Research in Second Language Teaching and Learning. Mahwah, N.J.: Lawrence Erlbaum Associates.

VanPatten, B., \& Oikkenon, S. (1996). Explanation vs. structured input in processing instruction. Studies in Second Language Acquisition, 18, 495-510. http://dx.doi.org/10.1017/S0272263100015394

Wajnryb, R. (1990). Grammar Dictation. Oxford: Oxford University Press.

Wilkins, D. A. (1976). Notional Syllabus. Oxford: Oxford University Press.

Williams, J., \& Evans, J. (1998). What kind of focus and on which form? In C. Doughty, \& J. Williams (Eds.), Focus on form inclassroom second language acquisition (pp. 139-155). Cambridge: Cambridge University Press. 